\title{
Learning Japanese through Anime
}

\author{
Yee-Han Chan \\ Faculty of Languages and Linguistics, University of Malaya, Malaysia \\ Ngan-Ling Wong \\ Faculty of Languages and Linguistics, University of Malaya, Malaysia
}

\begin{abstract}
While studies have confirmed that there is apparent connection between interest in anime and Japanese language learning among the Japanese language learners (Manion, 2005; Fukunaga, 2006; William, 2006; Abe, 2009), the practical use of anime in teaching Japanese Language as a Foreign Language has not been studied in depth. The present study aimed to discover the language features that can be learned by the Japanese language learners through critical viewing of anime in classroom. A course named "Learning Japanese language through Anime" was carried out in one public university in Malaysia for a duration of 10 weeks. Along with the administration of the course, the participants' worksheets on language analysis and learning diaries were collected. The findings showed that language used in anime is more casual in most of the contexts involving daily life. This language use is quite different from what the students usually listen to and use in the classroom where the educators heavily emphasis on the polite ways of speaking using the material designed specifically for pedagogical purposes such as textbooks. Although at times, the language presented in anime maybe even harsh or rough in an exaggerated way, rather than ignore this, it may be better to address it critically under the guidance of educator.
\end{abstract}

Index Terms-anime, classroom activities, role language, popular culture, teaching Japanese as a Foreign Language

\section{INTRODUCTION}

The study of popular culture is now becoming an emerging research area within the field of education and many studies have found success putting popular culture to work in the language classroom (Frey \& Fisher, 2004; Alim \& Pennycook, 2007; Black, 2008). Frey and Fisher (2004) made use of graphic novels to enhance their students' reading and writing abilities. Alim and Pennycook (2007) found that hip-hop culture and rap are highly popular among youth worldwide and has been recognized as influential transformative educational tool despite their controversial position in mainstream education. According to Black (2008), incorporating popular culture in the classroom could unite the students and encourage possible connection with one another based on their interest outside of school.

In the case of teaching Japanese as a Foreign Language (JFL), while studies have confirmed that there is apparent connection between interest in anime and Japanese language learning among the Japanese language learners (Manion, 2005; Fukunaga, 2006; William, 2006; Abe, 2009), the practical use of anime in teaching JFL has not been studied in depth. The present study aimed to discover the language features that can be learned by the Japanese language learners through critical viewing of anime in classroom.

\section{REVIEW OF RELATED LITERATURE}

\section{A. Cartoon and Anime}

There are numerous ways of defining anime. Anime is often associated and compared with the concept of cartoon. Napier (2005) states that,

"To define anime simply as 'Japanese cartoons' gives no sense of the depth and variety that make up the medium. [...] Essentially, anime works include everything that Western audiences are accustomed to seeing in live-action films romance, comedy, tragedy, adventure, even psychological probing of a kind seldom attempted in recent mass-culture Western film or television. [...] Unlike cartoons in the West, anime in Japan is truly a main-stream pop cultural phenomenon" (p. 6-7).

From Napier's statement, the clear distinction between cartoon and anime could be observed. Aeschliman (2007) explained that while the term anime is used as a blanket term to refer to all animation from all over the world in Japan, many dictionaries in English define anime as a style of animation developed in Japan. In view of the definitions above, the term anime is used to define and distinct animation made in Japan with other region's animation (cartoon) in this paper.

\section{B. The Use of Cartoon in Language Classroom}

Bahrani and Soltani (2011) claimed that cartoons have been effective in increasing the motivation of language learners by being an authentic audiovisual language. "Cartoons are good sources of modified language input which 
although may require less cognitive processing for comprehension, they may include new aspects of the language for low level language learners who have not acquired them yet" (Bahrani \& Soltani, 2011, p. 19).

Bahrani and Soltani (2011) encouraged the use of cartoons in lessons because cartoons can provide variation for the brain as "visual information in the form of cartoons is usually processed by the right brain which is the holistic, creative, artistic side" while "the spoken word engages the left side of the listeners' brain" which "is analytical, recognizes and interprets words, performs calculations and so on" (p. 20). No matter how convincing and interesting the lesson is, after a short period of time, the learners will start to feel the dullness of the same manner of teaching involving the constant use of the left side of the brain. A cartoon, on the other hand, is a kind of visual information and is processed by the right side of the brain. Therefore, cartoons can be utilised as a tool for variety and creativity in keeping the learners less bored (Bahrani \& Soltani, 2011).

Barker (2009) explained that making the learners interactive is the best way to keep them interested and engaged in lessons. Adapting cartoons into the classroom with suitable and applicable activities can promote the learners' observational, analytical, and higher thinking skills. "Cartoons can spark thoughtful conversation, and open the doors for a teacher and the student to discuss current events, social and family life, values, morals, and religious philosophies. They give insight into the world around us, and provide opportunities for genuine and meaningful communication" (Oliveri, 2007, p. 2).

Arikan and Taraf (2010) investigated the effectiveness of authentic animated cartoon "The Simpsons" in teaching English to young learners. The results indicated that the learners in the experimental group (watched and made use of "The Simpsons" as classroom material) performed better "in learning target grammar points and vocabulary items" (p. 212) as compared to the control group (followed a traditional grammar-based syllabus). Valez Gea (2013) showed that "children learn new vocabulary, expressions, other accents, different manners of speaking English, thanks to current famous music groups and popular cartoons" (p. 202). Munir (2016) also suggested that cartoon film is effective to teach vocabulary to EFL learners.

The use of cartoons in the ESL and EFL classroom has shown positive effect in improving students' language competence (Arikan \& Taraf, 2010; Velez Gea, 2013; Munir, 2016). This suggested the possibility of anime to serve as an effective teaching tool in the JFL classroom.

\section{Role Language (Yakuwarigo)}

The research of the Japanese language used by imaginary characters in media such as novels, dramas, and anime is closely associated with the concept of "role language" (known as "yakuwarigo" in Japanese). "Yakuwarigo" is a term coined by Kinsui in 2003. Kinsui (2003) defined role language as,

"When hearing a certain way of word-usage, one can call to mind a certain image of a person (age, sex, job, class, era, appearance, looks, personality etc), or, when one is presented with a certain image of a person, one can call to mind the word-usage that person would be sure to use, we call that word-usage 'role language"' (as cited in Fäldt, 2006, p. 17).

Media characters in certain subgroups, e.g., gender, age, regional affiliation, socioeconomic status, and personal traits, are attached to "specific sociolinguistic expectations" (Hiramoto, 2010) to project their stereotypical roles. Many stereotypical linguistic styles can be observed from a character's role language, including "first-person and secondperson pronouns, copula, negation, progressive form, etc." (Westman, 2010, p. 23), but the most important indicators are the pronouns (especially the first-person pronoun) and the sentence end expression (Kinsui, 2003, p. 205). Kinsui has illustrated his concept of role language using some variations of a very basic sentence (see Table 1).

TABLE I

EXAMPLES OF THE VARIATIONS OF ROLE LANGUAGE (KINSUI, 2003, P. 68).

\begin{tabular}{|l|l|l|}
\hline No & Expression & Character \\
\hline 1 & Sou yo, atashiga shitte iru wa & Girl \\
\hline 2 & Sou da, washi ga shitte oru & Old professor \\
\hline 3 & Soya, wate ga shittoru dee & Kansai-area people \\
\hline 4 & Sou ja, sesshag a zonjite oru & Samurai warrior \\
\hline 5 & Sou desu wa yo, watakushi ga zonjite orimasu wa & Princess-like girl \\
\hline 6 & Sou aru yo, watashi ga shitteru aru yo & Fake Chinese \\
\hline 7 & Sou da yo, boku ga shitte iru no sa & Boy \\
\hline 8 & Nda, ora shitteru da & Country bumpkin \\
\hline 9 & Sou desu, watashi ga shitte imasu. & Gender-neutral standard form \\
\hline
\end{tabular}

In Table 1, all the expressions from (1) to (8) have the same meaning as expression (9) "Sou da, watashi ga shitte $i r u$ " which means "Yes, I know". The role language indicators, such as the Japanese copula $d a$, first-person pronouns, and sentence-final particles are italicised in bold (see Table 1). The role language indicators are usually identically used by the same character image in different anime. For example, the samurai characters from different anime are likely to adapt the same expression pattern of refereeing to oneself as "sessha" (watashi, which means "I"). By looking at the different expressions used by different character images from (1) to (8), it can be safely said that the language usage in (9) is not role language, as it does not suggest any specific character image to the reader. In other words, the role language level in (9) is close to "zero" (Kinsui, 2003, p. 68). The reason it is not zero is because the usage of polite form still indicates a level of social context. 
These stereotypical linguistic styles are well-known and recognized by all Japanese native speakers but they are not commonly used in real life. Thus, Kinsui regards role language as "virtual Japanese", but Kinsui also argued that role language is not totally unrelated to reality. It plays important parts in real life by representing one's persona when the speaker "wants to appear in a certain way (masculine, feminine, joking, etc.)" (Westman, 2010, p. 8).

\section{METHODOLOGY}

The present study was aimed to answer the research question: What language features can be learned from watching anime? To address the research questions, the present study was conducted using classroom research method and collect qualitative data via the participants' worksheets and learning diaries.

\section{A. The Participants}

The present study used purposeful homogenous sampling in order to choose participants with similar backgrounds and experiences (Patton, 1990). The participants involved comprised of 11 students (9 females and 2 males). They were aged between 20 and 21 and have particular interest in Japanese popular culture such as anime, manga (Japanese comic or graphic novel), J-pop music, J-drama, video games, and cosplay (the practice of dressing up as a character from a movie, book, or video game). All the 11 participants involved were lower-intermediate learners in their second year of JFL studies in one public university of Malaysia. All the participants have learnt the Japanese language for at least 18 months and have at the minimum passed the Japanese-language Proficiency Test (JLPT) Level N4.

The JLPT is the largest-scale Japanese language test in the world. It has five levels: N1, N2, N3, N4 and N5 with the easiest and lowest level being N5 and the most difficult and highest level being N1. Student who has passed the JLPT Level N4 at the minimum seems to be a suitable participant for the present study because according to the JLPT website, student who has passed Level N4 will be "able to listen and comprehend conversations encountered in daily life and generally follow their contents, provided that they are spoken slowly” (The Japan Foundation, 2012).

The participants' profiles are presented in Table 2 below.

TABLE II

PARTICIPANTS' PROFILES.

\begin{tabular}{|l|l|l|l|l|}
\hline No. & Name & Age & Gender & Interests \\
\hline 1 & Alice & 20 & Female & Anime, manga, light novels \\
\hline 2 & Betty & 21 & Female & Anime, J-pop music \\
\hline 3 & Evelyn & 21 & Female & Anime, J-drama, J-pop music \\
\hline 4 & Frank & 20 & Male & Anime, J-pop music, video games \\
\hline 5 & Kevin & 20 & Male & Anime, manga, J-drama, J-pop music, video games \\
\hline 6 & Mandy & 21 & Female & Anime, J-drama \\
\hline 7 & Nancy & 21 & Female & Anime, manga, J-pop music \\
\hline 8 & Natalie & 21 & Female & Anime, manga, cosplay, J-drama, J-pop music, video games \\
\hline 9 & Olivia & 21 & Female & Anime, manga \\
\hline 10 & Sharon & 20 & Female & Anime, manga, J-pop music \\
\hline 11 & Susan & 21 & Female & Anime, manga, J-drama \\
\hline
\end{tabular}

The participants were asked to fill out consent form to grant the researcher permission to make use of the data obtained. To protect the confidentiality of the participant, all participants' names appearing in this paper are pseudonyms.

\section{B. The Procedures}

A course named "Learning Japanese language and Culture through Anime" was planned and conducted. The course was carried out in a local public university for a duration of 10 weeks. The participants were required to attend the course once a week. Time allocated for each lesson was approximately 120 minutes. All the lessons took place in a classroom equipped with a projector, computer, and connection to the internet. Table 3 illustrates the course outline for this 10-week course. 
TABLE III

COURSE OUTLINE

\begin{tabular}{|c|c|c|c|}
\hline \multicolumn{4}{|l|}{ Number of Week } \\
\hline & Anime & Themes & Classroom activities \\
\hline Week 1 & \multicolumn{3}{|l|}{ Course introduction } \\
\hline $\begin{array}{l}\text { Week 2 } \\
\text { (Lesson 1) }\end{array}$ & $\begin{array}{l}\text { Working!! } \\
\text { (Episode 1) }\end{array}$ & $\begin{array}{l}\text { Workplace conversation } \\
\text { Japanese surnames }\end{array}$ & $\begin{array}{l}\text { Active viewing } \\
\text { Follow-up discussion }\end{array}$ \\
\hline $\begin{array}{l}\text { Week } 3 \\
(\text { Lesson 2) }\end{array}$ & $\begin{array}{l}\text { Hanasaku Iroha } \\
\text { (Episode 1) }\end{array}$ & $\begin{array}{l}\text { Workplace conversation } \\
\text { Japanese traditional inn (ryokan) }\end{array}$ & $\begin{array}{l}\text { Active viewing } \\
\text { Follow-up discussion }\end{array}$ \\
\hline $\begin{array}{l}\text { Week } 4 \\
(\text { Lesson R1) }\end{array}$ & Revision lesson 1 & Refer to Lesson 1 and 2 & $\begin{array}{l}\text { Repetition of short scenes } \\
\text { Follow-up discussion }\end{array}$ \\
\hline $\begin{array}{l}\text { Week 5 } \\
\text { (Lesson 3) }\end{array}$ & $\begin{array}{l}\text { Kimi to Boku S2 } \\
\text { (Episode 13) }\end{array}$ & $\begin{array}{l}\text { School conversation } \\
\text { Japanese tea ceremony (sadou) }\end{array}$ & $\begin{array}{l}\text { Active viewing } \\
\text { Follow-up discussion }\end{array}$ \\
\hline $\begin{array}{l}\text { Week 6 } \\
\text { (Lesson 4) }\end{array}$ & $\begin{array}{l}\text { Hanasaku Iroha } \\
\text { (Episode 19) }\end{array}$ & $\begin{array}{l}\text { School conversation } \\
\text { Cultural festival (bunkasai) }\end{array}$ & $\begin{array}{l}\text { Active viewing } \\
\text { Follow-up discussion }\end{array}$ \\
\hline $\begin{array}{l}\text { Week } 7 \\
\text { (Lesson 5) }\end{array}$ & $\begin{array}{l}\text { Kimi to Boku } S 2 \\
\text { (Episode 1) }\end{array}$ & $\begin{array}{l}\text { Family conversation } \\
\text { Japanese bath (ofuro) }\end{array}$ & $\begin{array}{l}\text { Active-viewing } \\
\text { Follow up discussion }\end{array}$ \\
\hline $\begin{array}{l}\text { Week 8 } \\
\text { (Lesson R2) }\end{array}$ & Revision Lesson 2 & Refer to Lesson 3, 4, and 5 & $\begin{array}{l}\text { Repetition of short scenes } \\
\text { Follow-up discussion }\end{array}$ \\
\hline Week 9 & \multicolumn{3}{|c|}{ Concluding lesson } \\
\hline Week 10 & \multicolumn{3}{|c|}{ Participants' presentation of "My favourite anime" } \\
\hline
\end{tabular}

The most important points to be considered when selecting a video to be used in the classroom include the class objective, the learners' needs, and cultural appropriateness. Other technical aspects such as the length of the video, the availability of hardware, visual quality, and compatibility should be considered as well (Mokhamad Syaifudin, 2010).

The selection criteria for anime in the present study are as follows:

- Class objectives: To teach the Japanese language and culture simultaneously and to expose the participants with authentic spoken language input

- Anime length: Approximately 20-minute long episode from a TV animated series

- Themes: Simple daily life

- Language: Match with the participants' proficiency (lower intermediate)

- Content Appropriateness: Free of violence, nudity, and excessive profanity

- Availability: Legally purchased DVD and used for non-profit educational purpose

The selected TV animated series were Working!!, Hanasaku Iroha (The Blooming Colours), and Kimi to Boku S2 (You and Me).

\section{Classroom Activities}

The classroom activities carried out included active viewing, repetition, and follow-up discussion.

(1) Active viewing: Unlike passive viewing where the viewer is only exposed to the video content but does not engage with the video content at any critical level, active viewing requires the viewer to identify and analyse the viewing experience. Before the active viewing of anime, the participants were guided with a pre-viewing briefing. The pre-viewing briefing was important to inform the participants about the general background of the anime. The trailer of the respective anime was shown to the participants by using YouTube website. During the active viewing activity, the participants' were asked to start analysing the language used in the characters' dialogues and jot down keywords of what they noticed on the analysis worksheet given.

(2) Repetition: Prior to the lesson, the researcher identified several scenes with important or difficult dialogues. The dialogues lines in these 1 to 3 minutes short scenes were then transcribed. During the lesson, these transcripts were distributed to the participants. The participants were given time to read the dialogue lines and then the repetition activity was carried out by replaying the scenes one by one. The participants were divided into groups of three to discuss and analysis the dialogue transcripts and then record their findings with examples on the analysis worksheet given.

(3) Follow-up discussion: The follow-up discussion activity was used to stimulate communication among the participants, as well as to develop sharing and co-operative skills. This activity was also important to let the participants express their personal responses about the anime, justify any misunderstanding of cultural issues portrayed, and to relate the learning from anime to real life situations.

\section{Data Collection}

The data were collected via the participants' worksheets and learning diaries.

For each active viewing lesson, the participants were given a worksheet and a transcript of dialogues in short scenes selected. These transcripts will aid the participants in recording their analysis of the language used in anime. The worksheets were completed in the Japanese language and collected five times (Lesson 1, Lesson 2, Lesson 3, Lesson 4, and Lesson 5). A total of 55 completed worksheets $(n=11)$ were collected. The function of these worksheets was to provide evidence and examples of language features noticed and learned by the participants.

Apart from recording the students' own learning and skill development during the classroom learning process, learning diaries contain the students' record of their own experiences, thoughts, feelings and reflections. The participants were given option to write their diaries in whichever language they felt most comfortable with when 
recording their thoughts. All the participants chose to write their diaries in English. The learning diaries were collected 7 times ( 5 active viewing lessons and 2 revision lessons) and a total of 77 diaries $(n=11)$ were collected. The functions of these learning diaries were to: (1) provide evidence of understanding of the knowledge taught in the classroom, and (2) record the participants' feelings, impressions, and experiences in the classroom.

\section{FINDINGS AND DisCUSSION}

It should be noted that the findings presented were based on the participants' worksheets and learning diaries. Hence, the language features listed and presented were neither an exhaustive list nor do they address the precise contextual factors. It was the list of notions generated from the participants in the present study and there may be items missing to what has been explored by linguists.

The participants were found to be able to notice and learn the language features such as:

- Different levels of politeness (文体 - buntai)

- Casual forms

- Sentence-final particles

(くだけた-kudaketa)

- Pronouns

(終助詞 - shuujyoshi)

- Honorific suffix

(代名詞 - daimeishi)

- Swear words

(接尾辞 - setsubiji)

(污い言葉 - kitanaikotoba)

\section{A. Different Levels of Politeness}

In Japan, the Japanese people use different forms of language in different domains; for example when they speak to an elderly people or customers in business, they use the Japanese honorific form; to colleagues or friends they use the polite form; to close friends and family members, they use the plain form naturally (Wong, 2010). Although the politeness levels of spoken language were portrayed as such in the anime selected, there were some exceptions and unexpected styles were also used. The participants were found to be able to notice and identify proper and improper politeness levels through the repetition activity by looking at the human relationships (see Table 4 and Table 5).

TABLE IV

CONVERSATION BETWEEN TEACHER AND STUDENT IN THE ANIME KIMI TO BOKU S2 (EPISODE 13).

\begin{tabular}{|c|c|}
\hline Human relationship & Dialogue transcript \\
\hline Teacher and student & 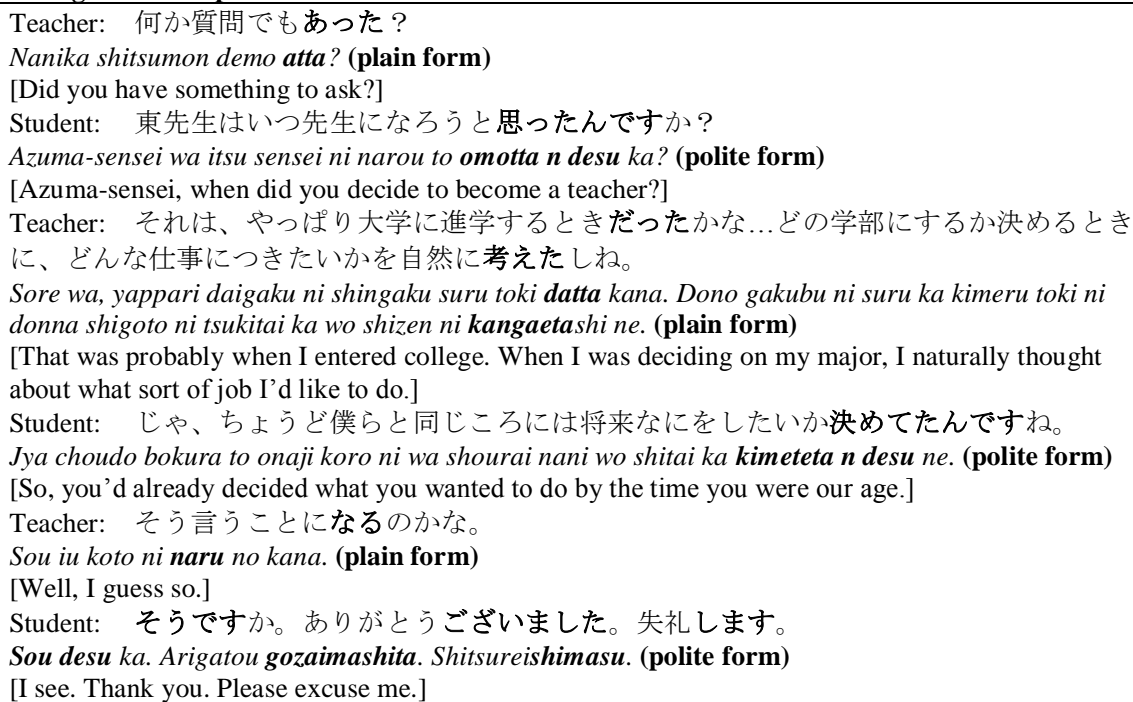 \\
\hline
\end{tabular}

In Table 4, the student used polite forms when talking to the teacher and the teacher replied in plain forms. This is a common and proper use of politeness level, but the participants noticed that this is different from the real life situation they experienced. For example, Alice expressed that,

"When I'm talking to sensei (teacher), I always speak in - masu form (polite form) to show my respect to sensei. My sensei also talks to me in -masu form. However, in this anime, Asuma-sensei (the male teacher in Kimi to Boku) used plain form when he is talking to the students. I think it is up to the sensei to choose his or her speech style when talking to the students because sensei has higher status than students" (Alice, diary 3). 
TABLE V

\begin{tabular}{l} 
UNEXPECTED SPEECH STYLES USED IN THE CONVERSATION BETWEEN CUSTOMER AND WAITER IN THE ANIME WORKING!! (EPISODE 1). \\
\begin{tabular}{|l|l|}
\hline Human relationship & Dialogue transcript \\
\hline Customer and Waitress & Customer: ねえ、ちよつと。このお占暖房効きすぎよ。何とかしてちょうだい。 \\
& Nee, chotto. Kono o-mise danbou kikisugi yo. Nantoka shite choudai. (plain form) \\
& [Excuse me. This restaurant's heat is turned up too high. Do something about it.] \\
& Waiter: なら外に出てその醜い脂肪を燃やしてこい。 \\
& Nara soto ni dete sono minikui shibou wo moyashite koi. (imperative in plain form) \\
& [Then go outside and burn off some of that ugly fat.]
\end{tabular} \\
\hline
\end{tabular}

In Table 5, the waitress' speech style was considered as an unexpected style because in a normal context, she should be using respectful or polite form when talking to the customer.

According to Sharon and Natalie,

"Today I learned about the conversation between customer and waiter in a famiresu (family restaurant). The waitress was very rude. She talked to the customer in meirei-kei (imperative). I think this is not right under normal situations" (Sharon, diary 1).

"The waitress was very fierce. She treated the customer in a very rude manner" (Natalie, diary 1).

In contrast to the native speakers of the Japanese language, the foreign language learners often learn the polite form before the plain form. One of the common problems of JFL learners is lack of exposure to informal settings in real life situations. Hence, they lack exposure to the usage of plain forms. Frank related his own situation with the character in anime by mentioned that,

"In the anime, close friends are talking to each other using plain form or casual form, but I still talk to my friends in polite form" (Frank, diary 5).

The majority of anime use a high school as the story background or setting because education is one of the fundamental systems in Japanese society (Napier, 2005) and most of the conversations that take place in these anime involves the use of plain or casual speech styles between friends, family members, people who are of similar age, and similar social status. Although the learners can be exposed to some formal speech styles depending on the anime selected, they are in fact listening to more informal speech styles (plain forms and casual forms) in anime. Therefore, to solve the problem of lack of exposure to informal speech styles in real life situation, Japanese language educators can consider using anime as a source of informal speech styles input for the learners.

\section{B. Casual Form}

"Informal colloquial styles are hard to acquire even for learners living in Japan because those styles are used only among people whose relationships are close" (Yoshida, 2010, p. 3). The informal colloquial styles are very closely related to the casual form (kudaketa), which is usually only used among close friends and family members. The casual form "uses plain verb endings and allows abundant contractions, colloquialisms" (Politeness and formality in Japanese, n.d.). Casual form is also influenced by local dialects. Anime with a school and family setting could be used to introduce different kinds of casual speech styles. Table 6 summarises the examples of casual forms noticed by the participants.

TABLE VI

CASUAL FORMS.

\begin{tabular}{|c|c|c|}
\hline No. & Casual form & Standard form \\
\hline $\mathrm{C} 1$ & $\begin{array}{l}\text { 決めてない。 } \\
\text { Kimete nai. } \\
\text { [I’ve not decided] }\end{array}$ & $\begin{array}{l}\text { 決めていない。 } \\
\text { Kimete inai. } \\
\text { (Worksheet 2) }\end{array}$ \\
\hline $\mathrm{C} 2$ & $\begin{array}{l}\text { お前の親はすげえ。 } \\
\text { Omae no oya wa sugee. } \\
\text { [Your parents are awesome] }\end{array}$ & $\begin{array}{l}\text { お前の親はすごい。 } \\
\text { Omae no oya wa sugoi. } \\
\text { (Worksheet 2) }\end{array}$ \\
\hline $\mathrm{C} 3$ & $\begin{array}{l}\text { 先生に聞こえちやいますよ。 } \\
\text { Sensei ni kikoechai masu yo. } \\
\text { [The teacher will hear you.] }\end{array}$ & $\begin{array}{l}\text { 先生に聞こえてしまいますよ。 } \\
\text { Sensei ni kikoete shimaimasu yo. } \\
\text { (Worksheet 3) }\end{array}$ \\
\hline $\mathrm{C} 4$ & $\begin{array}{l}\text { 心配しちやった。 } \\
\text { Shinpai shichatta. } \\
\text { [I was worried.] }\end{array}$ & $\begin{array}{l}\text { 心配してしまった。 } \\
\text { Shinpai shite shimatta. } \\
\text { (Worksheet 4) }\end{array}$ \\
\hline $\mathrm{C} 5$ & $\begin{array}{l}\text { 学校の行事はちゃんと参加しな。 } \\
\text { Gakkou no gyouji wa chanto sanka shina. } \\
\text { [You need to participate in school event.] }\end{array}$ & $\begin{array}{l}\text { 学校の行事はちやんと参加しなさい。 } \\
\text { Gakkou no gyouji wa chanto sanka shinasai. } \\
\text { (Worksheet 4) }\end{array}$ \\
\hline C6 & $\begin{array}{l}\text { 民ちにも知らせてあげなくちや。 } \\
\text { Min-chi ni mo shirasete agenakucha. } \\
\text { [We must inform Min-chi too.] }\end{array}$ & $\begin{array}{l}\text { 民ちにも知らせあげなければ（なりません）。 } \\
\text { Min-chi ni mo shirasete agenakereba (narimasen). } \\
\text { (Worksheet 4) }\end{array}$ \\
\hline
\end{tabular}

Although some of the participants found the casual forms difficult to learn, the participants were interested to know more about the conjugation patterns of the casual forms. Some of the participants' commented that, 
"Today, sensei (teacher) explained the conjugation rules to some of the kudaketa (casual) forms. I heard a lot of chau or -chatta in anime before, but I didn't know the meaning. Now I learned that they are the kudaketa forms of teshimau and -teshimatta" (Nancy, diary 2).

"The kudaketa forms are very hard to learn, but I think it is fun to know more about them because they appear quite often in anime" (Betty, diary 4).

"At first I thought kudaketa form is not important because I don't use it often in the real life situations. However, now I think I should know more about it if I want to become a full fledge Japanese language speaker because it seems to be quite important in natural spoken Japanese" (Evelyn, diary 4).

Language register refers to the level of formality with which you speak. Generally, when you speak under different situations or speak with different people will call for different registers (Eaton, 2012). For example, formal register for academic writing and business meeting and casual register for conversation among friends and family members. When learning a foreign language in a classroom, it is a common practice that the beginner learners will start to learn the formal register in the target language. For most people, the goal of foreign language learning is to achieve near-native speaker competence. To achieve this goal, the language learners of intermediate and advance level will need to familiarise themselves with informal and casual registers in order for them to sound more natural and make friends with the native speakers. Knowing how to differentiate between formal and informal speech styles and when to use them will definitely help the foreign language learners to fit in with the target language society better.

\section{Sentence-final Particles}

Japanese women's speech (joseigo or onna no kotoba) is typically described as more "polite, gentle, soft spoken, non-assertive, and empathetic" (Okamoto, 1995, p. 298) as compared to Japanese men's speech (danseigo or otoko no kotoba). One of the features that could be observed in the Japanese gendered speech styles is the sentence-final particles (SFPs). Table 7 summarises the examples of SFPs noticed by the participants.

TABLE VII

SENTENCE-FINAL PARTICLES.

\begin{tabular}{|c|c|c|}
\hline No. & SFPs used by female characters. & \\
\hline S1 & $\begin{array}{l}\text { これを持って行く時に確認してくるわ。 } \\
\text { Kore wo motte iku toki ni kakunin shite kuru wa. } \\
\text { [I'll check on them when I take this out.] }\end{array}$ & (Worksheet 1) \\
\hline S2 & $\begin{array}{l}\text { Wいのかしら? } \\
\text { Ii no kashira? } \\
\text { [Is it okay?] }\end{array}$ & (Worksheet 1) \\
\hline S3 & $\begin{array}{l}\text { 私一人でお婆ちやん家、高校もそつち行くの。 } \\
\text { Watashi hitori de oba-chan uchi, koukou mo socchi iku no. } \\
\text { [I'm going to my grandma's house alone. I'll be going to school there too.] }\end{array}$ & (Worksheet 2) \\
\hline S4 & $\begin{array}{l}\text { あの制服、可愛いよね! } \\
\text { Ano seifuku, kawaii yo ne! } \\
\text { [That uniform is really cute!] }\end{array}$ & (Worksheet 2) \\
\hline No. & SFPs used by male characters & \\
\hline S5 & $\begin{array}{l}\text { このままじや、身を滅ぼすぞ。 } \\
\text { Kono mama jya, mi wo horobosu zo. } \\
\text { [If you continue on like this, you'll ruin yourself.] }\end{array}$ & (Worksheet 2) \\
\hline S6 & $\begin{array}{l}\text { ないなら別にいいんだ。 } \\
\text { Nai nara betsu ni iin da. } \\
\text { [That's fine if you don’t.] }\end{array}$ & (Worksheet 3) \\
\hline S7 & $\begin{array}{l}\text { お前ら傍から見てると相当ばかだぞ。 } \\
\text { Omae ra hata kara miteru to soutou baka da zo. } \\
\text { [You guys look like idiots from over here.] }\end{array}$ & (Worksheet 5) \\
\hline
\end{tabular}

The common feminine SFPs used by the female characters (S1-S4) included わ (wa), よ (yo), の (no), ね (ne), and かしら (kashira). The common masculine SFPs used by the male characters (S5-S7) included だ (da), and ぞ (zo).

Apart from the regular use of female and male SFPs, the participants also noticed some unexpected use of SFPs by certain female characters (see Table 8). 
TABLE VIII

UNEXPECTED USE OF SENTENCE-FINAL PARTICLES BY FEMALE CHARACTERS.

\begin{tabular}{|l|ll|}
\hline No. & Unexpected use of SFPs by female characters & \\
\hline S8 & $\begin{array}{l}\text { 私が店長の白藤杏子だ。 } \\
\text { Watashi ga tenchou no Shirafuji Kyouko da. } \\
{[\text { I'm the restaurant manager, Shirafuji Kyouko.] }}\end{array}$ & (Worksheet 1) \\
\hline S9 & $\begin{array}{l}\text { 種島、後は任せたぞ。 } \\
\text { Taneshima, ato wa makase ta } \text { zo. } \\
{[\text { Taneshima, I'll leave the rest to you.] }}\end{array}$ & (Worksheet 1) \\
\hline S10 & $\begin{array}{l}\text { あんたは今から うちの従業員だ。 } \\
\text { Anta wa ima kara uchi no juugyouin da. } \\
{[\text { As of today, you are an employee here.] }}\end{array}$ & (Worksheet 2) \\
\hline S11 & $\begin{array}{l}\text { 私はしっかり空気読む む人な んだ。 } \\
\text { Watashi wa shikkari kuuki yomu hito nan da. } \\
{[\text { I'm definitely someone who can read between the lines.] }}\end{array}$ & (Worksheet 4) \\
\hline
\end{tabular}

The participants related the unexpected use of SFPs by the female characters to their personalities as portrayed in the anime. For example, Frank stated that,

"I noticed that Todoroki (a female character in Working!!) uses a lot of ' $w a$ ' at the end of her speech. I think this goes well with her soft and gentle personalities. On the other hand, Kyouko (a female character in Working!!) is a manager with strong personality, so she tends to talk in a more masculine way. So it is not surprising at all when she uses ' $z o$ ', which usually used by men, to end her speech" (Frank, diary 1 ).

"Recently it has been observed that Japanese women's use of language is changing and women are taking on using more neutral and even masculine forms" (Ogawa 2006; Okamoto \& Sato 1992; Okamoto 1995; Okamoto 1996; Mizumoto 2006; cited in Hollis, 2013, p. 21). The findings from the participants' analysis of language used in anime reflected this phenomenon too. For example, the use of SFP, だ $(d a)$ in the example S8, S10, and S11. In example S9, a more masculine form of SFP, ぞ ( $z o$ ) was used. This finding showed that although some may perceive language used in anime as more incline towards the concept of virtual language or role language (Kinsui, 2003), language used in anime also portrays and reflects the language used in reality to a certain extent.

\section{Pronouns}

The participant learned the differences of the use of pronoun between different gender, seniority, and situation (formal and informal). In the anime selected, most of the female characters were found to use 私 (watashi) or あたし (atashi) to refer to "I" and あなた (anata) or あんた (anta) to refer to "you" and most of the male characters used 俺 (ore) or 僕 (boku) to refer to “I" and お前 (omae) and 君 (kimi) to refer to “you” accordingly.

However, the participants also noticed that there was an exception where the old landlady in Hanasaku Iroha used お 前 (omae) to refer to “you” and こいつ (koitsu) to refer to "this fellow" (see Table 9).

TABLE IX

UNEXPECTED USE OF PRONOUNS BY FEMALE CHARACTERS.

\begin{tabular}{|l|ll|}
\hline No. & Unexpected use of pronouns & \\
\hline P1 & $\begin{array}{l}\text { お前が緒花だね。 } \\
\text { Omae ga Ohana da ne. } \\
\text { [You must be Ohana.](Lesson 2, scene 3) }\end{array}$ & Worksheet 2 \\
\hline P2 & $\begin{array}{l}\text { こいつはお客様に失礼したんだとさ。 } \\
\text { Koitsu wa o-kyaku sama ni shitsurei shi tanda to sa. } \\
\text { [This fellow caused inconvenience to the customer.] }\end{array}$ & Worksheet 2 \\
\hline
\end{tabular}

Regarding this, Mandy commented,

"I think the language use of obaasan (grandmother) is quite interesting because she uses some otoko kotoba (men's language) and sounds quite rude. I think this is because she is an elderly person and the owner of ryokan (traditional Japanese inn). So she basically has the highest status next to the customers in ryokan" (Mandy, diary 2).

A male participant, Kevin felt that he should change the way he uses the first person pronoun by mentioning that,

"I always use 'watashi' to refer to myself in real life situations. I have get used to this, but I think I should try to use 'boku' (casual male first-person pronoun) and 'ore' (casual male first-person pronoun) when I'm talking to my close friends from now on because it will definitely sound more natural to the native speaker" (Kevin, diary 5).

Unlike the English language, pronouns in the Japanese language are usually omitted from sentences when they can be inferred from context. Through watching and analysing the language use under different contexts in anime, the Japanese language learners can learn how to use the pronouns as well as to understand when not to use them in order to speak the Japanese language naturally.

\section{E. Honorific Suffixes}

In the Japanese language, there is a broad array of honorific suffixes for addressing people. For instance, "-san", as in "Suzuki-san". The common ones include "-sama" and "-san" which are gender-neutral; "-kun" which is mainly used for 
young males and "-chan", which is mainly used for young females. Honorific suffixes are generally essential when referring to someone. Dropping the honorific suffix (yobisute) implies a high degree of intimacy and is usually reserved for very close friends, younger family members, or spouse. Table 10 and Table 11 summarise the findings noticed by the participants.

TABLE X

HONORIFIC SUFFIXES USED TO REFER TO FEMALE CHARACTERS.

\begin{tabular}{|l|ll|}
\hline No. & Honorific suffixes used to refer to female characters & \\
\hline H1 & $\begin{array}{l}\text { 民ち、まだご機嫌斜めなの? } \\
\text { Min-chi, mada go-kigen naname na no? } \\
\text { [Min-chi, are you still in bad mood?] }\end{array}$ & Worksheet 4 \\
\hline H2 & $\begin{array}{l}\text { 緒花ちやんだって期待してるよ。 } \\
\text { Ohana-chan datte kitai shite ru yo. } \\
\text { [Ohana-chan is looking forward to it.] }\end{array}$ & \\
\hline H3 & $\begin{array}{l}\text { よかったね、菜子ち。 } \\
\text { Yokatta ne, Nako-chi. } \\
\text { [It's great, Nako-chi.] }\end{array}$ & Worksheet 4 \\
\hline
\end{tabular}

TABLE XI

HONORIFIC SUFFIXES USED TO REFER TO MALE CHARACTERS.

\begin{tabular}{|l|ll|}
\hline No. & Honorific suffixes used to refer to male characters & \\
\hline H4 & $\begin{array}{l}\text { 要君のお母さんつて、みかん好きですかね? } \\
\text { Kaname-kun no okaasan tte mikan suki desu ka ne? } \\
\text { [Kaname-kun, does your mother like tangerines?] }\end{array}$ & Worksheet 5 \\
\hline H5 & $\begin{array}{l}\text { 春ちゃんっていい子だよな。 } \\
\text { Shun-chan tte ii ko da yo na. } \\
\text { [Shun-chan is such a good kid.] }\end{array}$ & Worksheet 5 \\
\hline
\end{tabular}

In H1 and H3, a special suffix "-chi" was used to refer to some female characters whereas in H5, the suffix "-chan" which is usually used to refer to female was used to refer to a male character. According to the participants, the uncommon honorific suffixes were used to show "cuteness" and "solidarity". Olivia and Susan think that,

"Usually in anime, there are a lot of yobikata (ways of addressing people) like '-san', '-chan', '-kun'. Today I saw another new yobikata '-chi' in the anime class. Actually I have come across other yobikata such as '-pyon' and 'chama' from other anime. I think this kind of yobikata is very cute" (Olivia, diary 4).

"Today we discussed about yobikata and yobisute (dropping the honorific suffix) in the class. I noticed that boys will usually yobisute when calling their friend's name, but Chizuru (a male character in Kimi to Boku) called Shun (a male character in Kimi to Boku) 'Shun-chan'. I think this is because Shun is quite girlish in personality or maybe Chizuru wanted to tease him or to show solidarity because they are best friends" (Susan, diary 5).

Honorific suffixes in anime appear to be more complicated than in real life situations. Apart from using the proper suffixes such as "-san", "-kun", and "-chan", special suffixes are used in place of proper suffixes. Different from proper suffixes, these special suffixes are invented based on the effect the speaker is trying to achieve (e.g., to show cuteness or affection). For example,

- "-tan": Derived from "-chan" to show cuteness.

- "-pyon": Indicating that the speaker is being very cutesy or affectionate with the person he or she is addressing.

- "-chama": The baby-talk version of "-sama".

The learners should be alerted about these special honorific suffixes which are known to be used more in anime than in real life in order to avoid misuse of these special honorific suffixes in real life communication.

\section{F. Swear Words}

A language classroom is probably not the place to learn swear words. However, to some extent, swear words, curse words, and insults do appear in authentic materials such as film, movie, drama, as well as anime. Table 12 presents some swear words identified by the participants.

TABLE XII

SWEAR WORDS

\begin{tabular}{|c|l|ll|}
\hline No. & Swear words or insults & Meaning & \\
\hline W1 & $\begin{array}{l}\text { ふざけるな! } \\
\text { Fuzakeruna! }\end{array}$ & Stop being stupid! & Worksheet 2 \\
\hline W2 & $\begin{array}{l}\text { 頭使え、アホ! } \\
\text { Atama tsukae, aho! }\end{array}$ & Use your brain, moron! & Worksheet 2 \\
\hline W3 & $\begin{array}{l}\text { バカ野郎! } \\
\text { Baka yarou! }\end{array}$ & Idiot! & Worksheet 3 \\
\hline
\end{tabular}

The participants were amused when identifying swear words in the anime. They also revealed that they actually already knew about these words from other anime, especially the shounen anime (anime targeted for boys). Kevin and Nancy revealed that, 
"It was amusing when we discussed the word 'aho' (moron) in the class. I came across this word in another anime before. I have a hunch that it is a bad word, but I did not know the exact meaning. In the class discussion, Nancy (one of the participants) said ' $a h o$ ' means ' $b a k a$ ' (stupid) in Kansai (Western Japan) dialect' (Kevin, diary 2).

"I like to watch shounen anime. In most of the shounen anime, there are a lot of dirty words such as 'kisama' (rude way of saying 'you'), 'temee' (rude way of saying 'you'), 'kusogaki' (brat), and so on. Actually we use word like ' $b a k a$ ' to joke with each other in class occasionally. I think this is one way to show solidarity if you didn't mean it seriously. Also, I guess it is just a common nature for students to pick up dirty words naturally from media" (Nancy, diary 3$)$.

The main purpose of swearing is to express the speaker's emotional state, especially anger and frustration and communicating that information to the listener (Jay \& Janschewitz, 2008). Although swearing is accepted as a social phenomenon in English speaking countries, American Indians, Japanese, Malayans and most Polynesians do not have swear words in their languages (Montagu, 1967, p. 55). Some researchers recognized Japanese as a "swearless" language.

“As a matter of fact, there are some swearwords in Japanese like 'chikusho' (animal, beast) or 'kuso' (shit), however there are hardly anywhere near as many as the English ones, so that Japanese has been deemed an officially 'swearless' language" (Kosugi, 2010, p. 31).

Nonetheless, Jackson and Kennett (2012) challenged the myth that Japanese is a "swearless" language by looking at popular publications that educate the Japanese language learners in swearing. As a result, Jackson and Kennett (2012) raised the issue of whether swearing should be formally introduced through the curriculum.

The findings of the present study showed that swear words can be identified in anime. In fact, many anime, especially shounen anime, are known to have a lot of combat scenes where the characters are angry with each other and yelling swear words to show their anger. Therefore, the researcher thinks that common swear words used in anime or other type of media should be pointed out to the learners in order to warn them about the inappropriate uses of the swear words.

\section{CONCLUSION}

Napier confirms that anime reaches "far beyond the children's cartoon and often portrays important social and cultural themes" (Napier, 2005: back cover). However, according to Spindler (2010), "there are mixed opinions on the authenticity of the language and culture presented in anime and manga". Some have suggested that the language and culture portrayed in anime are merely representations of exaggerated and distorted version of the actual language and culture. In contrast, some have argued that there is something to be learned from anime, particularly if the learner has a firm "Japanese culture knowledge base" (p. 51).

Spindler (2010) believed that cultural knowledge base such as the understanding of the inner and outer circles in the hierarchical social system of the Japanese "would serve as a good sieve to help sift through the inaccuracies and exaggerations of the portrayed language and culture they are receiving from anime and manga" (p. 51). For example, the language used in anime is more casual in most of the contexts involving daily life. This language use is quite different from what the students usually listen to and use in the classroom where the educators heavily emphasis on the polite ways of speaking using the material designed specifically for pedagogical purposes such as textbooks.

It is a fact that educators cannot control what the students learn and see outside the classroom. One of the main concerns about the learners' interest in anime is that they may make broad judgments or assumptions about the Japanese language and culture based solely on the anime they watched. Since many studies have shown that anime has become a significant presence in most of the Japanese language learners, it has become part of the Japanese language educators' responsibility to dispel language and cultural stereotypes in anime. For example, students should be reminded not to expect the Japanese to talk exactly as in anime and not to use the words or phrases learned from the anime until they are certain of the meanings. This explains why anime should be introduced in the JFL classroom not just because it can serve as good teaching material, but also to raise the learners' consciousness on language and cultural stereotypes in anime.

\section{REFERENCES}

[1] Abe, K. (2009). American students' interests in the Japanese language: What Japanese language teachers should be aware of. Master's thesis, Baylor University, US.

[2] Aeschliman, L. (2007). What is anime?. Bella Online. http://www.bellaonline.com/articles/art4260.asp (accessed 23/2/2013).

[3] Alim, S. H., \& Pennycook, A. (2007). Glocal linguistic flows: Hip-hop culture(s), identities, and the politics of language education. Journal of Language, Identity, and Education, 6(2), 89-100. Doi: 10.1080/15348450701341238.

[4] Arikan, A., \& Taraf, H. U. (2010). Contextualizing young learners' English lessons with cartoons: Focus on grammar and vocabulary. Procedia Social and Behavioral Sciences, 2, 212-215. Doi: 10.1016/j.sbspro.2010.03.848.

[5] Bahrani, T., \& Soltani, R. (2011). The pedagogical values of cartoons. Research on Humanities and Social Sciences, 1(4), 1922.

[6] Barker, L. (2009). Interactive teaching techniques. http://www.ehow.com/way_5408150_interactive-teaching-techniques.html (accessed 11/6/2013).

[7] Black, R. W. (2008). Adolescents and online fan fiction. New York: Peter Lang Publishing Inc. 
[8] Eaton, S. E. (2012). Language register and why it matters: Why you can't write an academic paper in gangsta slang. https://drsaraheaton.wordpress.com/2012/05/22/language-register-and-why-it-matters-or-why-you-cant-write-an-academicpaper-in-gangsta-slang/ (accessed 20/6/2013).

[9] Fäldt, K. (2006). The conjectural and hortative bee: From dialectal particle to stereotypic marker. Sweden: Centre for Languages and Literature, Lund University.

[10] Frey, N., \& Fisher, D. (2004). Using Graphic Novels, Anime and the Internet in an Urban High School. English Journal, 93(3), 19-25. Doi: $10.2307 / 4128804$.

[11] Fukunaga, N. (2006). Those anime students: Foreign language literacy development through Japanese popular culture. Journal of Adolescent \& Adult Literacy, 50(3), 206-222. Doi: 10.1598/jaal.50.3.5.

[12] Hiramoto, M. (2010). Anime and intertextualities: Hegemonic identities in Cowboy Bebop. Pragmatics and Society, 2010, 1(2), 234-256. Doi: 10.1075/ps.1.2.03hir.

[13] Hollis, L. (2013). Anime and the real world gendered use of sentence final particles across genres. Griffith Working Papers in Pragmatics and Intercultural Communication, 6, 20-27.

[14] Jackson, L. B., \& Kennett, B. (2012, August). Learning to swear in Japanese: An analysis of popular resources. Paper presented at Sociolinguistics Symposium 19, Freie Universität Berlin, Germany.

[15] Jay, T., \& Janschewitz, K. (2008). The pragmatics of swearing. Journal of Politeness Research, 4(2), 267-288. Doi: 10.1515/jplr.2008.013.

[16] Kosugi, H. (2010). Performative power of language: Japanese and swearing. Jurnal Teknosastik, 8(2), 30-37.

[17] Kinsui, S. (2003). Vaacharu nihongo yakuwarigo no nazo [Virtual Japanese: The mysteries of role language]. Tokyo: Iwanami Shoten.

[18] Manion, A. (2005). Discovering Japan: Anime and learning Japanese culture. Master's thesis, Univeristy of Southern California, US.

[19] Mokhamad Syaifudin. (2010). Making the most of video sharing websites: An Indonesian scenario. CALL-EJ Online, 11(2), 29-39.

[20] Montagu, A. (1967). The anatomy of swearing. Philadelphia: University of Pennsylvania Press.

[21] Munir, F. (2016). The effectiveness of teaching vocabulary by using cartoon film toward vocabulary mastery of EFL students. Journal of English Language Teaching and Linguistics, 1(1), 13-37. Doi: 10.21462/jeltl.v1i1.20.

[22] Napier, S. (2005). Anime from Akira to Howl's Moving Castle. New York: Palgrave MacMillan.

[23] Okamoto, S. (1995). 'Tasteless' Japanese: less 'feminine' speech among young Japanese women. In K. Hall, \& M. Bucholtz (Eds.), Gender articulated: Language and the socially constructed self (pp. 297-325). New York: Routledge.

[24] Oliveri, D. (2007). Cartoon drawing in the classroom: Ways to use cartoon in teaching. http://www.morguefile.com-tarr101 (accessed 13/6/2013).

[25] Patton, M. (1990). Qualitative evaluation and research methods. Beverly Hills, CA: Sage.

[26] Politeness and formality in Japanese. (n.d.). Japanese professor. http://www.japaneseprofessor.com/lessons/beginning/politeness-and-formality/ (accessed 30/9/2015).

[27] Spindler, W. (2010). Anime and manga, Japanese foreign language students, and the assumption popular culture has a place in the classroom. Master's thesis, University of California, United States.

[28] The Japan Foundation. (2012). N1-N5: Summary of linguistic competence required for each level. http://www.jlpt.jp/e/about/levelsummary.html (accessed 2/4/2013).

[29] Valez Gea, N. L. (2013). Learning and teaching of English in a foreign language classroom of primary education through current songs and cartoons. Odisea, 14, 183-204.

[30] Westman, F. (2010). Words of the Japanese shadow: A study of Jungian archetypes and Japanese role language. Bachelor's Thesis, Lund University, Sweden.

[31] William, K. L. (2006). The impact of popular culture fandom on perceptions of Japanese language and culture learning: The case of student anime fans. Austin, Texas: University of Texas Libraries.

[32] Wong, N. L. (2010). Silent communication in Japanese society. Kuala Lumpur: University of Malaya Press.

[33] Yoshida, M. (2010). The cognitive processes of Japanese as foreign language learners in understanding videos. Master's thesis, University of Malaya, Kuala Lumpur, Malaysia.

Yee-Han Chan is a postgraduate candidate at the Faculty of Languages and Linguistics, University of Malaya, Malaysia. Her research interests include teaching Japanese as a Foreign Language, educational technology, and Japanese popular culture.

Ngan-Ling Wong is senior lecturer attached with the Faculty of Languages and Linguistics, University of Malaya, Malaysia. She teaches Japanese at the Department of Asian and European Languages. Her research and publications support intercultural communication focusing on the use of silence in Japanese and Malaysian societies. Her present study is related to investigating Malaysian Japanese language learners' language acquisition competence and behavioural changes resulted from participating the study abroad program to Japan. 